\title{
Attempt at the assessment of the infuence of the education on the level of knowledge of legal regulations concerning nursing profession among nurses
}

\begin{abstract}
Introduction. The profession of a nurse should be practised along with the standards of the most recent medical knowledge and law.

Aim. The authors aimed at assessing the relationship between nurse's education and their knowledge of the legal regulations, taking into account nurses' performance at work.

Material and methods. A total of 91 nurses were included in the study group. The mean age of the nurses was 34 years (min. 22, max. 63). Group 1: 32 nurses with medium-level education, group 2: 59 nurses with higher-level education. The study tool was a voluntary and anonymous survey questionnaire the authors' own design, consisting 36 questions. The results obtained were subjected to statistical analysis using STATISTICA 10.0 (Medical University of Warsaw licence), nonparametric U MannWhitney Test $\alpha<0.05)$.

Results. 69 nurses declared they knew the legal acts regulating their profession, Group 2 members were significantly more likely to know them $(\mathrm{p}<0.007)$. Nurses with higher education were statistically more likely to be aware of the independent character of the profession they practised $(\mathrm{p}<0.002)$. Most nurses were aware of their right to refuse a doctor's order in case it is noncompliant with their conscience $(\mathrm{p}=\mathrm{NS})$.

Conclusions. Even though the respondents had relatively good knowledge of legal regulations concerning their profession, it needs to be complemented, for instance through postgraduate education. In the study group, education affected the level of knowledge of nurses. Particular attention should therefore be given to the provision of complementary knowledge of the principles of practising the profession of a nurse to the group of nurses with medium-level education.
\end{abstract}

Keywords: nursing, law, higher education, medium-level medical education.

DOI: $10.1515 /$ pjph-2016-0016

\section{INTRODUCTION}

Nurses should work according to the standards of the most recent medical knowledge, Evidence-Based Nursing Practice, as well as the current legal regulations. The legal principles of nursing practice in Poland are regulated by the law concerning the professions of nurses and a midwives, issued on the $15^{\text {th }}$ of July 2011 [1].

According to the law, a nurse is an independent practitioner. The essence of the profession is to provide medical and nursing services. Moreover, nurses co-operate with physicians when performing medical procedures. In particular, the nurse is expected to act along with physician's recommendations. Yet, in some cases, the nurse may refuse to follow doctors' orders. This mainly concerns situations where the procedure is not compliant with nurses' qualifications or conscience (theso-called conscience clause). There are also some healthcare procedures, which the nurse is able to provide without doctors' recommendations or supervision). These procedures are mentioned in the regulation issued by Ministry of Health [2].

In addition, nurses have some legal duties, only loosely related to their profession. For example, they are expected to inform the patient about his or her rights. It applies to whole area of nurse healthcare activity. Moreover, it is the nurse who is expected to obtain a written consent from the patient for every procedure that is being perfomed. Plus to that, when nurse refuse to perform physicians' order, they also have to inform their superior about it in a written form [1].

Nurses and midwives, like medical doctors, or architects have also their own governing body. The activity of this body is regulated by Law on the self-government of nurses and midwifes of $1^{\text {st }}$ July 2011 [3]. Every nurse or midwife is expected to become a member of the body.

Not every nurse is aware of their duties. In case of legal (formal) duties, the situation seems to be even worse. From the other side, being aware of these duties may have a significant impact on patients' safety. This means, it is essential to their practising of the profession of a nurse.

There are differences in levels of knowledge about the principles of nursing profession and legal duties among various groups of nurses. The potential factors that may have some impact on the level of nurses' knowledge and awareness are: professional experience, age or place of work and their education in particular. 


\section{AIM}

The authors aimed at assessing the relationship between nurse's education and their knowledge of the legal regulations taking into account nurses' performance at work.

\section{MATERIAL AND METHODS}

A total of 91 nurses, employees of the Independent Public Central Teaching Hospital of Medical University of Warsaw participated in the study. Their average job experience was, 11 years (min. 2 months, max. 41 years). The respondents were aged 34 on average (min. 22 years, max. 63 years).

The research group has been divided on the basis of the educational level. The first group consisted of 32 nurses with medium-level education, while the second group consisted of 59 nurses with higher-level education (holding a bachelor's or master's degree).

The study was voluntary and anonymous. The authors used a questionnaire survey.as a study tool. The questionnaire of the authors' own design included 36 questions including 32 closed, single or multiple choice questions and demographic data questions.

The authors performed a statistical analysis using STATISTICA 10.0 (Medical University of Warsaw licence). Descriptive statistics and nonparametric U Mann-Whitney Test to assess the significance of the comparison have been applied. Assumed apriori level of statistical significance was equal $\alpha<0.05$.

\section{RESULTS}

Most nurses claim that they know the legal acts related to the principles of the nursing profession. Nurses with higher education were more likely to be familiar with these documents, unlike their colleagues with medium-level education $(\mathrm{p}<0.007)$.

More than a half of the respondents knew that nursing is an independent medical profession. In this respect, there was a clear correlation between the nurse's education and being aware of this $(\mathrm{p}<0.022)$.

A vast majority of nurses knew that every nurse is protected by law, as a public servant when at work. One's educational level had no significant impact in this respect.

Nurses were also generally aware that the principles of their profession are described in Law on the profession of a nurse and a midwife issued on the $15^{\text {th }}$ of July 2011 . The better one's education, the more likely they were to know about it $(p<0.001)$. On the other hand, most respondents were unable to mention the act regulating the scope of procedures that can be performed by nurses and midwives without doctor's supervision. No significant differences between research groups have been found.

Almost all respondents knew about the conscience clause, which is a kind of a professional privilege that nurses enjoy. A vast majority knew also that when they refuse to execute an order, they have to justify their decision to the physician who ordered the procedure or to the superior nurse. They are obliged to provide a written explanation. Knowledge of nurses in this area did not differ with respect to education level.

The law on the profession of a nurse and a midwife of $15^{\text {th }}$ July 2011 also regulates the requirements related to the postgraduate education of nurses. The survey contained a few questions regarding this issue. More than a half of respondents knew, that nurse can start a post-graduate specialization after two years of professional experience, while less than a half of the respondents knew that a qualification course is admissible after one has worked as a nurse for at least 6 months. In both cases, there were significant differences between research groups - again, nurses with higher education scored better.

Some questions referred to the Law on the self-government of nurses and midwives of $1^{\text {st }}$ July 2011 . Only $1 / 3$ of respondents knew that this act regulates the activity of professional body of nurses and midwives. About a half of them was aware that the membership in self-government is mandatory for every nurse and midwife. Concerning the other issue, nurses with higher education had significantly better knowledge $(p<0.031)$. More details are presented below, in Table 1 .

\section{DISCUSSION}

The issue of nurses' knowledge of legal acts regulating their profesion received much attention both among Polish and international researchers [4-8]. There are also some papers comparing the knowledge in this area with respect to level of education [7].

A huge change in the so-called nursing law happened on the $1^{\text {st }}$ of January 2012, when a new act on the professions of a nurse and a midwife (issued on the $15^{\text {th }}$ of July 2011) and the act on the professional self-government of nurses and midwives (issued on 1 July 2011) came into force. Until that time, only very few studies tackling the issue of legal awareness among nurses had been published. The authors of this very study attempted to investigate the knowledge of the largely amended law governing practicing the profession among nurses with different levels of education.

The authors' own research showed that most nurses were familiar with the legal acts governing their profession. And even though a vast majority of respondents knew the names of these legal acts, there is a significant group of nurses who are not aware of content of these laws. This cannot be considered as a surprise. Ozdemir et al conducted an interesting study in Turkey [4]. Their study showed that over a half of the nurses participating in the study had not read any legal act dealing with the patient's rights. Paradoxically enough, though, no statistically significant differences were found between the respondents who had got acquainted with the contents of the acts referred to and those who had not.

In the authors' own research, a vast majority of the respondents knew that their profession is regulated by Law concerning the profession of a nurse and a midwife. It shows that nurses generally know the main regulations concerning their profession or at least they know where to look for them. These findings correspond with those by Gawel and co-workers [5]. In his study, 79 percent of respondents were acquainted with the law on the professions of a nurse and a midwife.

Rozwadowska et al also investigated the issue of nurses' knowledge about the law [6]. The study showed that nurses have relatively good knowledge of regulations. For example, $96 \%$ of nurses and midwives asked by the authors knew that it is possible to refuse executing doctor's orders. Unfortunately, this study had been conducted before 2011, which was the year when a significant amendment of nursing law was introduced. 
The authors' own research suggests that nurses with higher education tend to have better awareness of the legal aspects than the nurses with medium-level education. Yet, in some cases the differences between these two groups were not significant.

Nurses' knowledge concerning nursing law was compared with respect of education level also by Grochans and coworkers [7]. The authors of the study looked at three groups of nurses: nurses with medium-level education, nurses who had a bachelor's and those who held a master's degree. Overall, there were significant differences between these groups. The results of Kruskal Wallis $(\mathrm{H})$ test and multiple comparisons (p-values) showed that nurses with bachelor's degree had most knowledge about it. There were no significant differences between the results achieved nurses with medium-level education and those who held a master's degree.

The knowledge of nurses and midwives about their selfgovernment organization is rather weak. The results are similar

TABLE 1. Knowledge of nurses concerning legal aspects of nursing profession. Correct answers have been bold.

\begin{tabular}{|c|c|c|c|c|c|}
\hline Question & Answer & Overall & Group I & Group II & $\begin{array}{c}\text { Difference } \\
\text { (p-value) }\end{array}$ \\
\hline \multirow{2}{*}{$\begin{array}{l}\text { 1. Do you know any legal acts } \\
\text { regulating the principles } \\
\text { of the nursing profession? }\end{array}$} & Yes & 69 & 19 & 50 & \multirow{2}{*}{$\mathrm{p}<0.007$} \\
\hline & No & 22 & 13 & 9 & \\
\hline \multirow{3}{*}{$\begin{array}{l}\text { 2. Do you regard nursing practice } \\
\text { as an independent medical } \\
\text { profession? }\end{array}$} & Yes & 49 & 10 & 39 & \multirow{3}{*}{$\mathrm{p}<0.022$} \\
\hline & No & 33 & 17 & 16 & \\
\hline & I do not know & 9 & 5 & 4 & \\
\hline \multirow{3}{*}{$\begin{array}{l}\text { 3. Is a nurse protected by law } \\
\text { as a public servant? }\end{array}$} & Yes & 73 & 28 & 45 & \multirow{3}{*}{ NS } \\
\hline & No & 9 & 9 & 0 & \\
\hline & I do not know & 9 & 4 & 5 & \\
\hline \multirow{4}{*}{$\begin{array}{l}\text { 4. Which of the following legal acts } \\
\text { defines the principles of nursing } \\
\text { profession? }\end{array}$} & Law on the profession of a nurse and a midwife of $15^{\text {th }}$ July 2011 & 70 & 18 & 52 & \multirow{4}{*}{$\mathrm{p}<0.001$} \\
\hline & Law on the self-government of nurses and midwifes of $1^{\text {st }}$ July 2011 & 0 & 0 & 0 & \\
\hline & Regulation of Ministry of Health of $7^{\text {th }}$ November 2007 & 6 & 4 & 2 & \\
\hline & I do not know & 15 & 10 & 5 & \\
\hline \multirow{4}{*}{$\begin{array}{l}\text { 5. Which of the following legal acts } \\
\text { regulates the scope of medical pro- } \\
\text { cedures, that can be performed by } \\
\text { nurses or midwives independently, } \\
\text { without doctor's recommendation }\end{array}$} & Law on the profession of a nurse and a midwife of $15^{\text {th }}$ July 2011 & 31 & 15 & 16 & \multirow{4}{*}{ NS } \\
\hline & Law on the health activity of $15^{\text {th }}$ April 2011 & 12 & 2 & 10 & \\
\hline & Regulation of Ministry of Health of $7^{\text {th }}$ November 2007 & 22 & 2 & 20 & \\
\hline & I do not know & 26 & 13 & 13 & \\
\hline \multirow{3}{*}{$\begin{array}{l}\text { 6. Can a nurse refuse to execute } \\
\text { an action which goes against } \\
\text { her conscience? }\end{array}$} & Yes & 89 & 30 & 59 & \multirow{3}{*}{ NS } \\
\hline & No & 0 & 0 & 0 & \\
\hline & I do not know & 2 & 2 & 0 & \\
\hline \multirow{4}{*}{$\begin{array}{l}\text { 7. What should a nurse do after } \\
\text { refusing to execute an action } \\
\text { recommended by a doctor? }\end{array}$} & To give reason of it to physician or superior in written form & 83 & 27 & 56 & \multirow{4}{*}{ NS } \\
\hline & To ask about the opinion another nurse & 1 & 0 & 1 & \\
\hline & To inform about it self-government of nurses and midwifes & 1 & 1 & 0 & \\
\hline & I do not know & 6 & 4 & 2 & \\
\hline \multirow{3}{*}{$\begin{array}{l}\text { 8. Should a nurse inform the patient } \\
\text { about their rights in procedures } \\
\text { performed by nurses? }\end{array}$} & Yes & 79 & 27 & 52 & \multirow{3}{*}{ NS } \\
\hline & No & 4 & 1 & 3 & \\
\hline & I do not know & 8 & 4 & 4 & \\
\hline \multirow{4}{*}{$\begin{array}{l}\text { 9. How many years of experience } \\
\text { are needed to start post-graduate } \\
\text { specialization }\end{array}$} & 1 year & 6 & 4 & 2 & \multirow{4}{*}{$\mathrm{p}<0.006$} \\
\hline & 2 years & 54 & 9 & 45 & \\
\hline & 4 years & 7 & 4 & 3 & \\
\hline & I do not know & 24 & 15 & 9 & \\
\hline \multirow{4}{*}{$\begin{array}{l}\text { 10. How much job experience should } \\
\text { a nurse have to start } \\
\text { a post-graduate } \\
\text { specialization course? }\end{array}$} & 6 months & 38 & 8 & 30 & \multirow{4}{*}{$\mathrm{p}<0.001$} \\
\hline & 8 months & 2 & 2 & 0 & \\
\hline & 12 months & 20 & 6 & 14 & \\
\hline & I do not know & 31 & 16 & 15 & \\
\hline \multirow{4}{*}{$\begin{array}{l}\text { 11. Which of the following acts } \\
\text { regulates the activity nurses' } \\
\text { and midwives professional } \\
\text { association? }\end{array}$} & Law on the profession of a nurse and a midwife of $15^{\text {th }}$ July 2011 & 22 & 12 & 10 & \multirow{4}{*}{ NS } \\
\hline & Law on the self-government of nurses and midwifes of $1^{\text {st }} \mathrm{July} 2011$ & 35 & 3 & 32 & \\
\hline & Regulation of Ministry of Health of $7^{\text {th }}$ November 2007 & 4 & 3 & 1 & \\
\hline & I do not know & 30 & 14 & 16 & \\
\hline \multirow{3}{*}{$\begin{array}{l}\text { 12. Does every nurse have to be } \\
\text { a member of the professional } \\
\text { association of nurses and midwives } \\
\text { (self-government of nurses)? }\end{array}$} & Yes & 46 & 22 & 24 & \multirow{3}{*}{$\mathrm{p}<0.031$} \\
\hline & No & 38 & 7 & 31 & \\
\hline & I do not know & 7 & 3 & 4 & \\
\hline
\end{tabular}


to study by Gaweł [5]. In his research, only 40 percent of nurses knew the law concerning the professional association of nurses and midwifes.

It needs emphasizing that the study has certain limitations. The research group was not extensive enough. Moreover, participants were not chosen at random, which means that the result cannot be regarded as representative for all Polish nurses. There is a need for continuing the study and conducting it on a wider group of nurses, including the individuals working at ambulatory wards.

\section{CONCLUSIONS}

1. In the study group, the level of knowledge of legal regulations concerning the profession of nurse is satisfactory, but needs to be complemented, for instance, within the framework of postgraduate education.

2. In the study group, there was a clear correlation between the nurses' education and knowledge. Most attention should therefore be given to teaching the knowledge of the principles of practising the profession of a nurse to the group of nurses with medium-level education.

3. The report was part of a pilot study, which means that the research should be continued on a large, more varied study group.

\section{REFERENCES}

1. Law on the profession of a nurse and a midwife of 15 July 2011.

2. Regulation of ministry of Health on scope of medical procedures, which can be performed by nurse and midwife independently, without physicians' order of 7th November 2007.

3. Law on the self-government of nurses and midwifes of 1st July 2011.

4. Ozdemir HM, Can O, Ergonen AT, et al. Midwives and nurses awareness of patients' rights. Midwivery. 2009;25:756-65

5. Gaweł G, Plater B, Potok H, Ogonowska D. Świadomość odpowiedzialności zawodowej wśród pielęgniarek. Probl Pielęg. 2010;18(2):105-10

6. Rozwadowska E, Krajewska-Kułak E, Kropiwnicka E, et al. Ocena znajomości ustawy o zawodzie pielęgniarki i położnej przez studentów pielęgniarstwa i położnictwa oraz pielęgniarki i położne. Probl Pielęg. 2010;18(4):443-54.

7. Grochans E, Głowacka T, Szkup-Jabłońska M, et al. Wpływ poziomu wykształcenia pielęgniarek na znajomość wybranych aktów prawnych wykorzystywanych w pielęgniarstwie. Probl Pielęg. 2011;19(4):463-7.

8. Oyetunde MO, Ofi BA. Nurses' Knowledge of legal aspects of nursing practice in Ibadan, Nigeria. J Nurs Edu Pract. 2013;3:9.

Corresponding author

Aleksander Zarzeka

81 Żwirki i Wigury Str., 02-091 Warszawa,

tel./fax: (22) 5720490 , (22) 5720491

E-mail: aleksander.zarzeka@wum.edu.pl 